\title{
Epigenetic silencing of the ANKRD26 gene correlates to the pro-inflammatory profile and increased cardio-metabolic risk factors in human obesity
}

\author{
Antonella Desiderio ${ }^{1,2+}$, Michele Longo ${ }^{1,2+}$, Luca Parrillo ${ }^{1,2 \dagger}$, Michele Campitelli, ${ }^{1,2}$, Giuseppe Cacace ${ }^{1,2}$, \\ Sonia de Simone ${ }^{1,2}$, Rosa Spinelli $i^{1,2}$, Federica Zatterale ${ }^{1,2}$, Serena Cabaro ${ }^{1,2}$, Pasquale Dolce ${ }^{3}$, Pietro Formisano ${ }^{1,2}$, \\ Marco Milone ${ }^{4}$, Claudia Miele ${ }^{1,2^{*}}$, Francesco Beguinot ${ }^{1,2^{*}+}$ and Gregory A. Raciti ${ }^{1,2+}$
}

\begin{abstract}
Background: Obesity is a major worldwide threat to human health. Increasing evidence indicates that epigenetic modifications have a major impact on the natural history of this disorder. Ankyrin Repeat Domain 26 (Ankrd26) is involved in the development of both obesity and diabetes in mice and is modulated by environmentally induced epigenetic modifications. This study aims at investigating whether impaired ANKRD26 gene expression and methylation occur in human obesity and whether they correlate to the phenotype of these subjects.

Results: We found that downregulation of ANKRD26 mRNA and hyper-methylation of a specific region of the ANKRD26 promoter, embedding the CpG dinucleotides - 689, - 659, and - 651 bp, occur in peripheral blood leukocytes from obese compared with the lean subjects. ANKRD26 gene expression correlates inversely to the percentage of DNA methylation at these $3 \mathrm{CpG}$ sites. Luciferase assays reveal a cause-effect relationship between DNA methylation at the 3 CpG sites and ANKRD26 gene expression. Finally, both ANKRD26 mRNA levels and CpG methylation correlate to body mass index and to the pro-inflammatory status and the increased cardio-metabolic risk factors of these same subjects.

Conclusion: Downregulation of the ANKRD26 gene and hyper-methylation at specific CpGs of its promoter are common abnormalities in obese patients. These changes correlate to the pro-inflammatory profile and the cardiometabolic risk factors of the obese individuals, indicating that, in humans, they mark adverse health outcomes.
\end{abstract}

Keywords: ANKRD26, Obesity, Epigenetic silencing, DNA methylation, Cardio-metabolic risk factors

\section{Background}

Obesity is a chronic disorder associated with high risks of adverse health outcomes [1]. It is also a major risk factor for several metabolic diseases, including impaired glucose tolerance, type 2 diabetes (T2D), dyslipidemia, hypertension, and cardiovascular diseases (CVDs) [2]. Because of its globally increasing prevalence, obesity is

\footnotetext{
*Correspondence: c.miele@ieos.cnr.it; beguino@unina.it

Antonella Desiderio, Michele Longo, and Luca Parrillo have equally contributed to this work as first authors.

Gregory A. Raciti and Francesco Beguinot have equally contributed to this work as last authors.

'URT Genomics of Diabetes, Institute of Experimental Endocrinology and Oncology, National Research Council, Via Pansini 5, 80131 Naples, Italy Full list of author information is available at the end of the article
}

one of the main clinical challenge in the twenty-first century $[1,3]$. However, the mechanistic factors leading to obesity remain, in most cases, unclear [4].

Current evidence indicates that the recent rise in obesity prevalence is determined by unhealthy gene-environment interactions [5, 6]. Several studies have also documented that environmental hits may cause epigenetic changes, which, in turn, alter gene function and affect disease susceptibility [7, 8]. Epigenetics has been proposed to link genes and environment and may contribute to the worldwide increase in obesity prevalence. Very recent findings, both in animal models and in humans, have also documented the relationship between the risk of obesity and the epigenetic impairment of gene function, which are

(c) The Author(s). 2019 Open Access This article is distributed under the terms of the Creative Commons Attribution 4.0 International License (http://creativecommons.org/licenses/by/4.0/), which permits unrestricted use, distribution, and 
closely associated with weight gain and metabolic traits [4, 9-14]. For instance, in a candidate gene study for the preproopiomelanocortin locus, Kuehen et al. have identified an epigenetic variant of $\mathrm{CpG}$ methylation that is associated with the individual risk for obesity [12]. Furthermore, Pfeiffer et al. have demonstrated that the gene expression and DNA methylation of their candidate gene, the hypoxia-inducible factor $3 A$, is related to adipose tissue dysfunction, making this gene an important factor involved in the etiology of obesity [13]. However, whether these associations are causal and the direction of the causations remains controversial. Some studies indeed suggest that alterations in DNA methylation are predominantly the result of increased body mass index (BMI)/adiposity typical of obesity $[14,15]$. In an association study of BMI and differential methylation, Mendelson et al. have demonstrated that among the 83 novel differentially methylated CpGs related to BMI, the alterated methylation at one only specific CpG site has a causal effect on BMI and adiposityrelated traits, while other $16 \mathrm{CpGs}$ were secondary to differences in BMI [14]. In a further association study, Wahl et al. have also reported that the changes in DNA methylation at the majority of the identified $187 \mathrm{CpG}$ sites are consequences and not the cause of adiposity [15]. Therefore, whether epigenetic changes affect obesity development or vice versa still represents an open question and will need to be assessed on a case-by-case basis.

Through a methylated DNA immuno-precipitation sequencing (MeDIP-seq) approach, we have recently demonstrated that high-fat feeding triggers a massive DNA methylation reprogramming in genes involved in developmental, metabolic, and transcriptional processes in mice [16]. In addition, our recently published findings in the mouse model have identified $A n k r d 26$ as a gene undergoing epigenetic changes in response to high-fat feeding [17]. High-fat exposure causes a specific hypermethylation of the Ankrd26 promoter at the - 436 and - 431 bp CpG sites, which is dependent upon enhanced binding of the de novo DNA methyltransferases $3 \mathrm{a}$ and $3 \mathrm{~b}$ to the same Ankrd26 promoter region. These changes are followed by downregulation of Ankrd26 expression in the white fat depots [17]. ANKRD26 is located at chromosome 10p12, a locus previously associated with maternally inherited obesity in humans [18]. Only two rare single-nucleotide polymorphisms (SNPs) at the ANKRD26 gene, the rs139049098 (minor allele frequency, MAF: $C=0.0004 / 2$ ) and the rs191015656 (MAF: $A=0.0004 / 2$ ), have been so far associated with severe obesity in humans [19]. Very recently, the ANKRD26 gene SNP, rs7081476 (MAF: $C=0.0541 / 271$ ), has been associated across multiple studies to a variety of diseases, including diabetes and CVDs, and to different endophenotypes, such as BMI, high-density lipoprotein cholesterol (HDL-C), triglycerides (TG), blood glucose, and hemoglobin A1c (HbA1c) [20]. In addition to ours, other groups have further described Ankrd26 as a gene involved in the regulation of feeding behavior and in the development of both obesity and diabetes in mice [21-23]. Mutant mice with a partial inactivation of this gene (Ankrd26 MT) show obese and diabetic phenotypes which result from marked hyperphagia rather than reduction in energy expenditure or activity [21, 22]. Indeed, the C-terminal deletion of this gene, in vivo, in the Ankrd26 MT mice, leads to defects in primary cilia formation in central nervous system areas which regulate both food intake and energy homeostasis [23].

Altogether, this evidence suggests that the Ankrd26 gene plays a key role in the events contributing to obesity development and related dysfunction. In this work, we aimed at investigating whether changes in mRNA levels or DNA methylation of the ANKRD26 gene occur in human obese individuals, and whether these changes correlate to altered levels of metabolic and inflammatory mediators in these subjects.

\section{Results \\ Metabolic and inflammatory characterization of lean and obese subjects}

Lean $(n=14)$ and obese $(n=20)$ adults of Caucasian ethnicity were recruited at the Federico II University of Naples and investigated in the present study. Each group included equal numbers of females and males. Clinical features of the two groups are shown in Tables 1 and 2 . Serum TG $(p<0.001)$ and low-density lipoprotein cholesterol (LDL-C; $p=0.037$ ) concentrations were increased and the serum levels of HDL-C $(p=0.002)$ were reduced in the obese compared with lean individuals. Also, the TG/HDL-C ratio, a described predictor of insulin resistance and cardiovascular risk [24-31], was increased in the obese subjects. No difference was found in either fasting blood glucose and serum total cholesterol (TC) levels between the two groups (Table 1). In addition, the obese individuals also featured an increase in serum level of C-reactive protein (CRP; $p<0.001$; Table 1 ) as well as in several pro-inflammatory cytokines and chemokines (Table 2).

\section{ANKRD26 mRNA expression is reduced in peripheral blood leukocytes (PBL) from obese subjects}

To determine whether changes of the ANKRD26 gene expression occur in the PBL from the obese subjects, quantitative real-time PCR analysis was performed in cDNA from all of the subjects recruited in the study. We found a $40 \%$ reduction of the ANKRD26 mRNA levels in PBL from the obese compared with the lean individuals (age-adjusted $p=0.027$; Fig. 1a). Also, the ANKRD26 gene transcriptional levels in PBL correlated positively to its mRNA expression in abdominal visceral 
Table 1 Anthropometric and biochemical features of lean ( $n=$ $14 ; 7$ males and 7 females) and obese ( $n=20 ; 10$ males and 10 females) individuals. For symmetrically distributed variables, data are shown as mean \pm SD and statistical difference between the two groups was tested by two-tailed unpaired Student's $t$ test. For skewed distributions, data are shown as median (first quartile-Q1; third quartile-Q3) and statistical differences between the two groups were tested using Mann-Whitney $U$ test. BMI, body mass index; TC, total cholesterol; $H D L-C$, high-density lipoprotein cholesterol; $L D L-C$, low-density lipoprotein cholesterol; TG, triglyceride; CRP, C-reactive protein

\begin{tabular}{llll}
\hline & Lean & Obese & $p$ value \\
\hline$n$ (males/females) & $14(7 / 7)$ & $20(10 / 10)$ & \\
Age (years) & $30.2 \pm 2.6$ & $37.0 \pm 5.6$ & $<0.001$ \\
BMl $\left(\mathrm{kg} \mathrm{m}^{-2}\right)$ & $22.3 \pm 2.7$ & $46.7 \pm 6.9$ & $<0.001$ \\
Glucose $\left(\mathrm{mg} \mathrm{dL}^{-1}\right)$ & $87.9 \pm 7.1$ & $95.4 \pm 37.3$ & n.s. \\
TC $\left(\mathrm{mg} \mathrm{dL}^{-1}\right)$ & $176.4 \pm 33.4$ & $179.1 \pm 37.3$ & n.s. \\
HDL-C $\left(\mathrm{mg} \mathrm{dL}^{-1}\right)$ & $63.9 \pm 20.4$ & $46.5 \pm 10.2$ & 0.002 \\
LDL-C $\left(\mathrm{mg} \mathrm{dL}^{-1}\right)$ & $94.9 \pm 31.6$ & $117.8 \pm 29.2$ & 0.037 \\
TG $\left(\mathrm{mg} \mathrm{dL}^{-1}\right)$ & $58.6(43.4 ; 83.6)$ & $119.5(90.2 ; 162.0)$ & $<0.001$ \\
TG/HDL-C ratio & $0.9(0.6 ; 1.9)$ & $2.6(1.8 ; 4.2)$ & $<0.001$ \\
CRP $\left(\mathrm{mg} \mathrm{L}^{-1}\right)$ & $0.2(0.1 ; 0.4)$ & $7.7(1.7 ; 14.4)$ & $<0.001$ \\
\hline
\end{tabular}

adipose tissue (VAT; $n=10 ; r=0.850$; age-adjusted $p=$ 0.014; Additional file 1: Figure S1). Within the obese group, the ANKRD26 gene expression was much lower in the metabolically unhealthy (MUO) compared with the metabolically healthy obese (MHO) subjects, as defined in [32] ( $p=0.004$; Table 3). Also, ANKRD26 mRNA levels in PBL correlated negatively to BMI ( $n=$ 34; $r=-0.494$; age-adjusted $p=0.002$; Fig. $1 \mathrm{~b}$ ), while no correlation was found between ANKRD26 gene expression in the PBL and age $(n=34 ; r=-0.226$; n.s. $)$.

DNA methylation at the CpG sites, - 689, - 659, and 651, is increased in PBL from obese subjects

To investigate whether the downregulation of ANKRD26 gene expression observed in the obese individuals is paralleled by changes in DNA methylation, we have initially performed a bioinformatics analysis of the ANKRD26 promoter region. Based on EMBOSS CpGplot analysis, a 629 bp CpG island, straddling the ANKRD26 transcription start site (TSS; - 277/+ $351 \mathrm{bp}$ ), was identified along with two regions enriched in CpG sites, respectively, at - 900/$600 \mathrm{bp}$ and at $-580 /-370 \mathrm{bp}$ upstream the TSS (Fig. 2a). An ANKRD26 gene promoter/Exon 1 region (- 991/+ 390 bp), embedding the CpG island and the CpG enriched regions, was thus divided in 5 consecutive sub-regions, which were termed S1 (- 991/- $693 \mathrm{bp})$, S2 (- 716/- 370 bp), S3 (- 349/- $48 \mathrm{bp})$, S4 (- 68/+ $157 \mathrm{bp})$, and S5 (+ $134 /+390 \mathrm{bp}$ ) (Fig. 2b), and a direct analysis of cytosine methylation at this region was subsequently performed by sequencing of bisulfite-converted DNA obtained from PBL of 3 individuals featuring the lowest and 3 featuring the highest BMI. In lean subjects, the bisulfite sequencing analysis of the $A N K R D 26$ gene promoter/Exon 1 region revealed a high-density DNA hyper-methylation at the

Table 2 Pro-inflammatory cytokine and chemokine features of lean ( $n=12 ; 6$ males and 6 females) and obese $(n=18 ; 9$ males and 9 females) individuals. Data are shown as median (first quartile-Q1; third quartile-Q3) and statistical differences between the two groups were tested using Mann-Whitney $U$ test. IL, interleukin; IFNY, interferon $Y$; TNFa, tumor necrosis factor a; IP-10, interferon gamma-induced protein 10; MCP1, monocyte chemotactic protein 1; MIP1, macrophage inflammatory protein 1; RANTES, regulated on activation, normal $T$ cell expressed, and secreted

\begin{tabular}{|c|c|c|c|}
\hline & Lean & Obese & $p$ value \\
\hline $\mathrm{IL}-1 \beta\left(\mathrm{pg} \mathrm{mL} \mathrm{L}^{-1}\right)$ & $3.1(2.7 ; 3.4)$ & $3.4(2.8 ; 4.5)$ & n.s. \\
\hline IL-6 $\left(p g \mathrm{~mL}^{-1}\right)$ & $4.1(3.0 ; 5.3)$ & $8.6(6.0 ; 11.1)$ & $<0.001$ \\
\hline $\mathrm{IL}-7\left(\mathrm{pg} \mathrm{mL}^{-1}\right)$ & $9.0(7.9 ; 12.0)$ & $13.1(8.8 ; 15.8)$ & n.s. \\
\hline IL-9 $\left(p g ~ m L^{-1}\right)$ & $83.9(59.0 ; 93.7)$ & $83.9(75.3 ; 96.7)$ & n.s. \\
\hline IL-12 (pg mL $\left.\mathrm{m}^{-1}\right)$ & $25.6(16.7 ; 40.1)$ & $49.2(34.9 ; 81.9)$ & 0.006 \\
\hline $\mathrm{IL}-17\left(\mathrm{pg} \mathrm{mL}^{-1}\right)$ & $125.9(111.0 ; 149.4)$ & $130.5(116.9 ; 164.1)$ & n.s. \\
\hline IFN- $\gamma\left(\mathrm{pg} \mathrm{mL}^{-1}\right)$ & $101.2(91.2 ; 113.9)$ & $108.3(85.4 ; 126.3)$ & n.s. \\
\hline TNF-a $\left(p g \mathrm{~mL}^{-1}\right)$ & $48.6(39.7 ; 52.7)$ & $47.2(39.0 ; 54.7)$ & n.s. \\
\hline IL-8 $\left(p g \mathrm{~mL}^{-1}\right)$ & $16.5(12.8 ; 18.2)$ & $31.9(22.0 ; 46.8)$ & $<0.001$ \\
\hline Eotaxin $\left(\mathrm{pg} \mathrm{mL}^{-1}\right)$ & $102.0(63.8 ; 127.0)$ & $116.3(78.6 ; 157.6)$ & n.s. \\
\hline IP-10 $\left(\mathrm{pg} \mathrm{mL}^{-1}\right)$ & $313.3(218.4 ; 850.3)$ & $619.6(528.5 ; 1095.1)$ & 0.021 \\
\hline MCP-1 $\left(\mathrm{pg} \mathrm{mL}^{-1}\right)$ & $7.0(4.3 ; 14.5)$ & $30.3(18.3 ; 39.5)$ & 0.001 \\
\hline MIP-1a $\left(p g \mathrm{~mL}^{-1}\right)$ & $2.7(2.6 ; 3.1)$ & $3.2(2.2 ; 4.5)$ & n.s. \\
\hline $\operatorname{MIP}-1 \beta\left(p g \mathrm{~mL}^{-1}\right)$ & $141.7(90.5 ; 244.9)$ & $202.6(162.3 ; 424.4)$ & 0.040 \\
\hline RANTES (pg mL ${ }^{-1}$ ) & $21480.8(15677.0 ; 24610.0)$ & 28724.8 (26390.0; 36752.0) & $<0.001$ \\
\hline
\end{tabular}


a

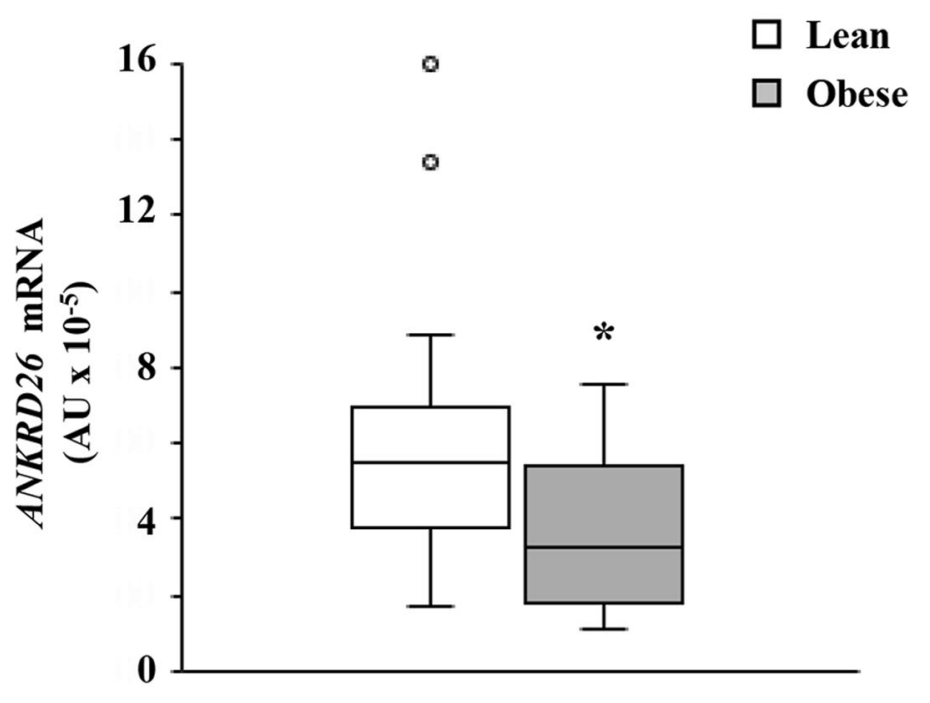

b

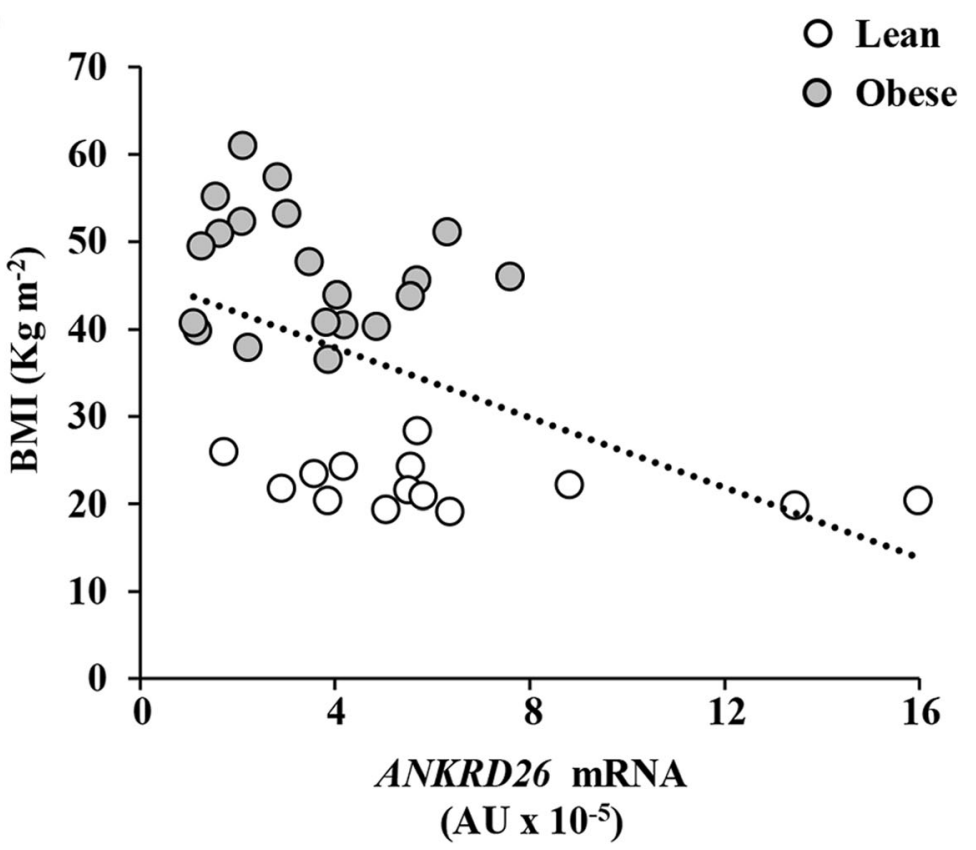

Fig. 1 ANKRD26 mRNA levels in PBL of lean and obese subjects. a ANKRD26 mRNA levels were determined in lean $(n=14)$ and obese $(n=20)$ subjects. Values are expressed in absolute units (AU) and their distribution within each group is represented by box plots. Box plots show median (line within the box), quartiles (upper and lower box boundaries), and extreme values (whiskers). Statistical differences between the two groups were tested using nonparametric quantile regression, with inference based on median, to adjust for age. $p=0.027$ vs. lean. $\mathbf{b}$ Relationship between BMl and ANKRD26 gene expression was assessed by covariate-adjusted Spearman's rank-order correlation adjusted for age. $n=34 ; r=-0.494 ; p=0.002$

sub-region $1(\mathrm{~S} 1 ; \sim 85 \%)$, a low/moderate CpG methylation at the $\mathrm{S} 2(\sim 20 \%)$, and a massive DNA hypomethylation at the sub-regions S3, S4, and S5 (Additional file 1: Table S1). Similar CpG methylation patterns were also observed at the sub-regions S1, S3, S4, and S5 of the ANKRD26 gene promoter/Exon 1 region in the obese individuals, while, in these patients, a significantly increased DNA methylation at the S2 $(\sim 27 \%$; $p<0.05)$ was found (Additional file 1: Table S1).
Based on these results, the DNA methylation pattern at the $\mathrm{S} 2$ was further investigated by extending sequencing analysis to bisulfite-converted DNA obtained from the PBL of 11 further lean and 17 further obese subjects. This additional sequencing revealed a $40-80 \%$ increased density of the DNA methylation at 3 close CpG dinucleotides (-689, -659 , and -651 bp from the ANKRD26 TSS) in the obese compared with lean subjects (Fig. 2c). DNA methylation at the $-689,-659$, and $-651 \mathrm{bp}$ 
Table 3 ANKRD26 mRNA levels and methylation percentage of the CpG sites, $-689,-659$, and - 651, in $\mathrm{MHO}(n=5)$ and MUO ( $n=15)$ individuals. Obese subjects have been classified as MHO or MUO based on Wildman et al. [32]. In particular, metabolically unhealthy obese subjects are defined by the presence of two or more of these 6 criteria: blood pressure systolic $\geq 130 \mathrm{mmHg}$ and/or diastolic $\geq 85 \mathrm{mmHg}$ or use of anti-hypertensive drugs; fasting triglycerides $\geq 150 \mathrm{mg} \mathrm{dl}^{-1}$ or use of lipid-lowering drugs; fasting $\mathrm{HDL}-\mathrm{C} \leq 40 \mathrm{mg} \mathrm{dL}^{-1}$ in men and $\leq 50 \mathrm{mg} \mathrm{dL}^{-1}$ in women or use of lipid-lowering drugs; fasting glucose $\geq 100 \mathrm{mg} \mathrm{dl}^{-1}$ or use of anti-diabetic drugs; HOMA-IR $>90^{\text {th }}$ percentile; and CRP $>90^{\text {th }}$ percentile, while metabolically healthy obese subjects are defined by the presence of 0 or 1 of the previous criteria. For symmetrically distributed variables, data are shown as mean \pm SD and the statistical difference between the two groups was tested by two-tailed unpaired Student's $t$ test. For skewed distributions, data are shown as median (first quartile-Q1; third quartile-Q3) and statistical differences between the two groups were tested using Mann-Whitney $U$ test. HDL-C, highdensity lipoprotein cholesterol; $T G$, triglyceride; $S B P$, systolic blood pressure; $D B P$, diastolic blood pressure; $C R P$, C-reactive protein; HOMA-IR, homeostatic model assessment of insulin resistance

\begin{tabular}{|c|c|c|c|}
\hline & $\mathrm{MHO}$ & MUO & $\begin{array}{l}p \\
\text { value }\end{array}$ \\
\hline \multicolumn{4}{|l|}{ Wildman criteria } \\
\hline Glucose, $\mathrm{mg} \mathrm{dL}^{-1}$ & $82.8 \pm 8.3$ & $99.6 \pm 42.3$ & n.s. \\
\hline $\mathrm{HDL}-\mathrm{C}, \mathrm{mg} \mathrm{dL}^{-1}$ & $53.8 \pm 13.6$ & $44.4 \pm 8.0$ & n.s. \\
\hline $\mathrm{SBP}, \mathrm{mmHg}$ & $119.0 \pm 10.2$ & $135.3 \pm 10.4$ & 0.007 \\
\hline $\mathrm{DBP}, \mathrm{mmHg}$ & $84.0 \pm 4.2$ & $85.0 \pm 6.0$ & n.s. \\
\hline $\mathrm{TG}, \mathrm{mg} \mathrm{dL}^{-1}$ & $\begin{array}{l}70.0(62.2 ; \\
119.5)\end{array}$ & $\begin{array}{l}137.0(104.0 ; \\
170.0)\end{array}$ & 0.036 \\
\hline $\mathrm{CRP}, \mathrm{mg} \mathrm{L}^{-1}$ & $2.0(0.5 ; 19.7)$ & $9.1(4.4 ; 17.2)$ & n.s. \\
\hline HOMA-IR & $1.6(1.4 ; 2.2)$ & $4.3(3.0 ; 5.7)$ & 0.006 \\
\hline ANKRD26 mRNA, AU $\times 10^{-5}$ & $5.7(4.4-7.0)$ & $2.2(1.6-3.8)$ & 0.004 \\
\hline $\begin{array}{l}\text { CpG - 689, \% CpG } \\
\text { methylation }\end{array}$ & $36.7 \pm 4.7$ & $57.8 \pm 15.7$ & 0.009 \\
\hline $\begin{array}{l}\text { CpG }-569, \% \text { CpG } \\
\text { methylation }\end{array}$ & $46.0 \pm 8.9$ & $51.2 \pm 19.3$ & n.s. \\
\hline $\begin{array}{l}C p G-651, \% \text { CpG } \\
\text { methylation }\end{array}$ & $54.0 \pm 16.7$ & $62.6 \pm 17.7$ & n.s. \\
\hline
\end{tabular}

CpG sites was increased by about 1.8 -fold (age-adjusted $p<0.001$ ), 1.9-fold (age-adjusted $p=0.040$ ), and 2.2-fold (age-adjusted $p=0.025$ ), respectively, in the obese compared with the lean (Fig. 2c). No relevant differences of DNA methylation were observed among normal weight and obese subjects at the CpG sites, $-522,-482,-452$, - 445, - 409, and - 402 bp (Fig. 2c). Also, within the obese group, the CpG site - $689 \mathrm{bp}$ was hypermethylated in the MUO compared with the MHO subjects $(p=0.009$; Table 3$)$, while no differences in CpG methylation were observed at the sites 659 and $-651 \mathrm{bp}$ (Table 3).
Methylation at the CpGs, $-689,-659$, and -651 , modulates ANKRD26 promoter activity in vitro

To identify a potential cause-effect relationship between the DNA methylation at the ANKRD26 gene promoter and its gene transcription, a DNA fragment $(-716 /-597 \mathrm{bp})$ containing the CpG sites, $-689,-659$, and $-651 \mathrm{bp}$, was cloned in a pCpG-free vector. Luciferase activities of either the in vitro $\mathrm{CpG}$ methylated or the un-methylated pCpG$A N K R D 26$ luciferase reporter vectors were then assayed in human embryonic kidney HEK293 cells. As shown in Fig. 2d, the un-methylated ANKRD26 promoter region induced a 2.2-fold increase of luciferase activity compared with the empty vector, indicating that this fragment features promoter activity. On the other hand, the methylation of the three selected CpG sites at the ANKRD26 promoter causes a 30\% reduction of the luciferase activity compared with the unmethylated pCpG-ANKRD26 luciferase vector, indicating that methylation of one or more of these $3 \mathrm{CpG}$ dinucleotides in vitro represses the ANKRD26 gene transcription. Also, a negative correlation was found between the combined methylation percentage at the cytosine residues -689 , - 659, and - 651 of the ANKRD26 promoter and the expression levels of the ANKRD26 gene in PBL $(n=34, r=-$ 0.539 , age-adjusted $p<0.001$; Fig. 3a). The combined methylation of these $3 \mathrm{CpG}$ sites positively correlated to BMI ( $n=$ $34, r=0.736$, age-adjusted $p<0.001$; Fig. 3b). No correlation was found between the combined DNA methylation at these 3 CpG sites and age $(n=34, r=-0.223, n . s)$. It is noteworthy that similar results were obtained when these relationships with ANKRD26 mRNA expression, BMI, and age were performed on individual CpG methylation percentages (Additional file 1: Table S2).

\section{Both ANKRD26 mRNA expression and CpG methylation associate with obesity-related endophenotypes}

We then explored whether changes of the ANKRD26 gene expression correlate to metabolic and inflammatory marks. As reported in Table 4, we found that ANKRD26 mRNA levels correlated inversely to serum TG concentration $(n=34, r=-0.630$, age-adjusted $p$ $<0.001)$ and directly to serum HDL-C concentration ( $n=34, r=0.647$, age-adjusted $p<0.001)$. In addition, the ANKRD26 gene expression correlated negatively to serum levels of CRP $(n=34, r=-0.494$, age-adjusted $p<0.001$ ), interleukin $1 \beta$ (IL- $1 \beta ; n=30, r=-0.498$, age-adjusted $p=0.010)$, IL-6 $(n=30, r=-0.401$, ageadjusted $p=0.027)$, IL-12 $(n=30, r=-0.506$, ageadjusted $p=0.002)$, IL-8 $(n=30, r=-0.650$, ageadjusted $p<0.001$ ), interferon gamma-induced protein 10 (IP-10; $n=30, r=-0.520$, age-adjusted $p=0.002)$, macrophage inflammatory protein $1 \alpha$ (MIP- $1 \alpha ; n=30$, $r=-0.513$, age-adjusted $p=0.006), \operatorname{MIP}-1 \beta(n=30, r$ $=-0.601$, age-adjusted $p<0.001)$, and normal $\mathrm{T}$ cell expressed and secreted (RANTES; $n=30, r=-0.476$, 
$\mathbf{a}$

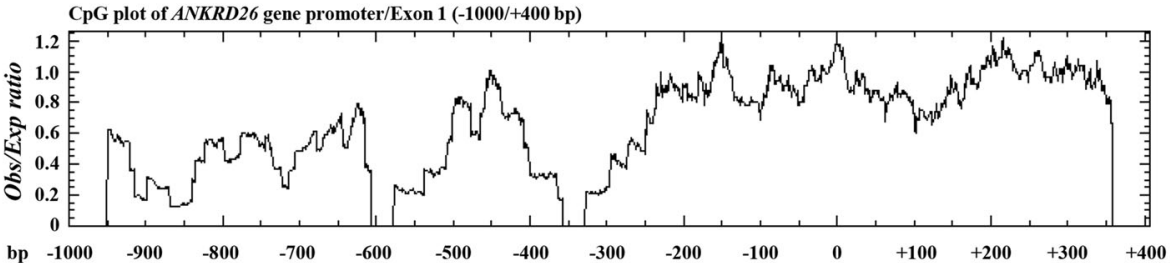

b

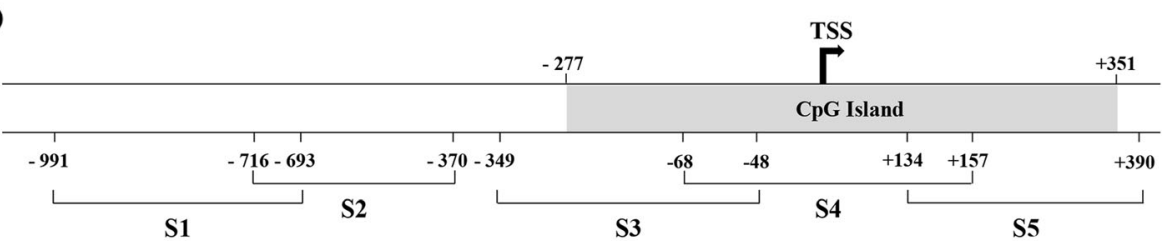

c
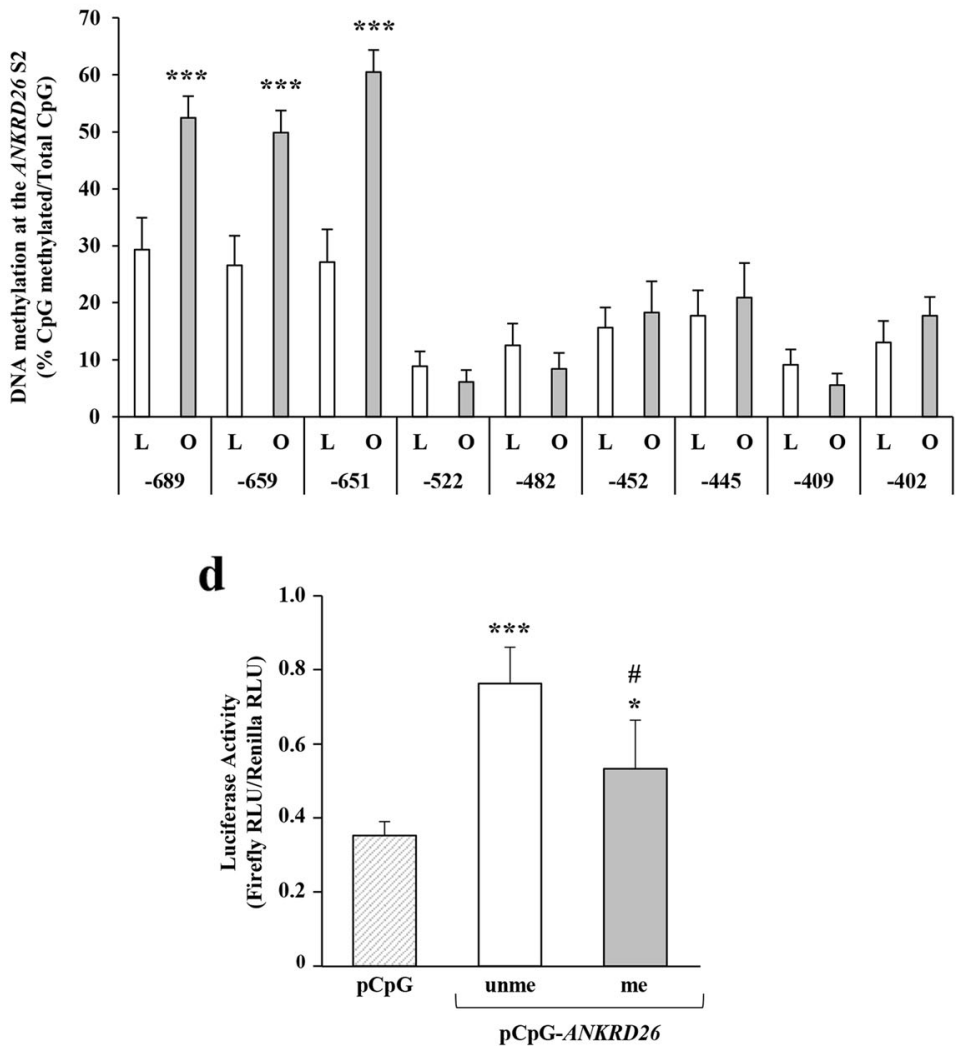

Fig. 2 ANKRD26 promoter methylation in PBL of lean and obese subjects and in vitro promoter activity. a A CpG plot of the ANKRD26 gene promoter/Exon 1 (- 1000/+ 400 bp from TSS) was determined by using the EMBOSS CpGplot software. The presence of a $629 \mathrm{bp} \mathrm{CpG} \mathrm{island,} \mathrm{straddling} \mathrm{the} \mathrm{ANKRD26} \mathrm{TSS} \mathrm{(-} \mathrm{277/+}$ $351 \mathrm{bp}$ ) and two regions enriched in CpGs, respectively, at - 900/- $600 \mathrm{bp}$ and at - 580/- 370 bp upstream the TSS were identified. Values in y-axis are the minimum average observed (Obs) to expected (Exp) ratio of C plus $\mathrm{G}$ to $\mathrm{CpG}$ in a set of 10 windows that are required before a $\mathrm{CpG}$ island is reported. The minimum length, that a CpG island has to be before it is reported, is $200 \mathrm{bp}$. A window is set by default to $100 \mathrm{bp}$. Values in the $x$-axis are base pairs. b Schematic representation of the ANKRD26 gene. Sub-region S1, - 991/- 693 bp; S2, - 716/- 370 bp; S3, - 349/- 48 bp; S4, - 68/+ 157 bp; S5, + 134/+ 390 bp. CpG Island, 250/- 50. TSS, transcription start site; 5'-UTR, untranslated region. c Bisulfite sequencing methylation analysis of the ANKRD26 S2 (CpG sites, - 689, - 659, - 651, $522,-482,-452,-445,-409,-402$ bp from the TSS) in converted genomic DNA from PBL of 14 lean and 20 obese subjects. Results are means \pm SD. Statistical difference between the means of the two groups was assessed by classical OLS regression model to adjust for age. ${ }^{* *} p<0.001 \mathrm{vs}$. lean \% CpG methylation. $\mathbf{d}$ Luciferase activity of in vitro CpG methylated (me) or un-methylated (unme) pCpG-ANKRD26 constructs and the pCpG empty vector was assessed as described in the "Methods" section. Firefly luciferase activity was normalized to Renilla luciferase activity. Luciferase activity is displayed in relative light units (RLU). Results are means \pm SD from three independent experiments. Statistical difference between the means of the groups was assessed by one-way ANOVA. ${ }^{*} p$ $<0.05$ and ${ }^{* * *} p<0.001$ vs. pCpG empty vector; ${ }^{*} p<0.05$ vs. pCpG-ANKRD26unme 


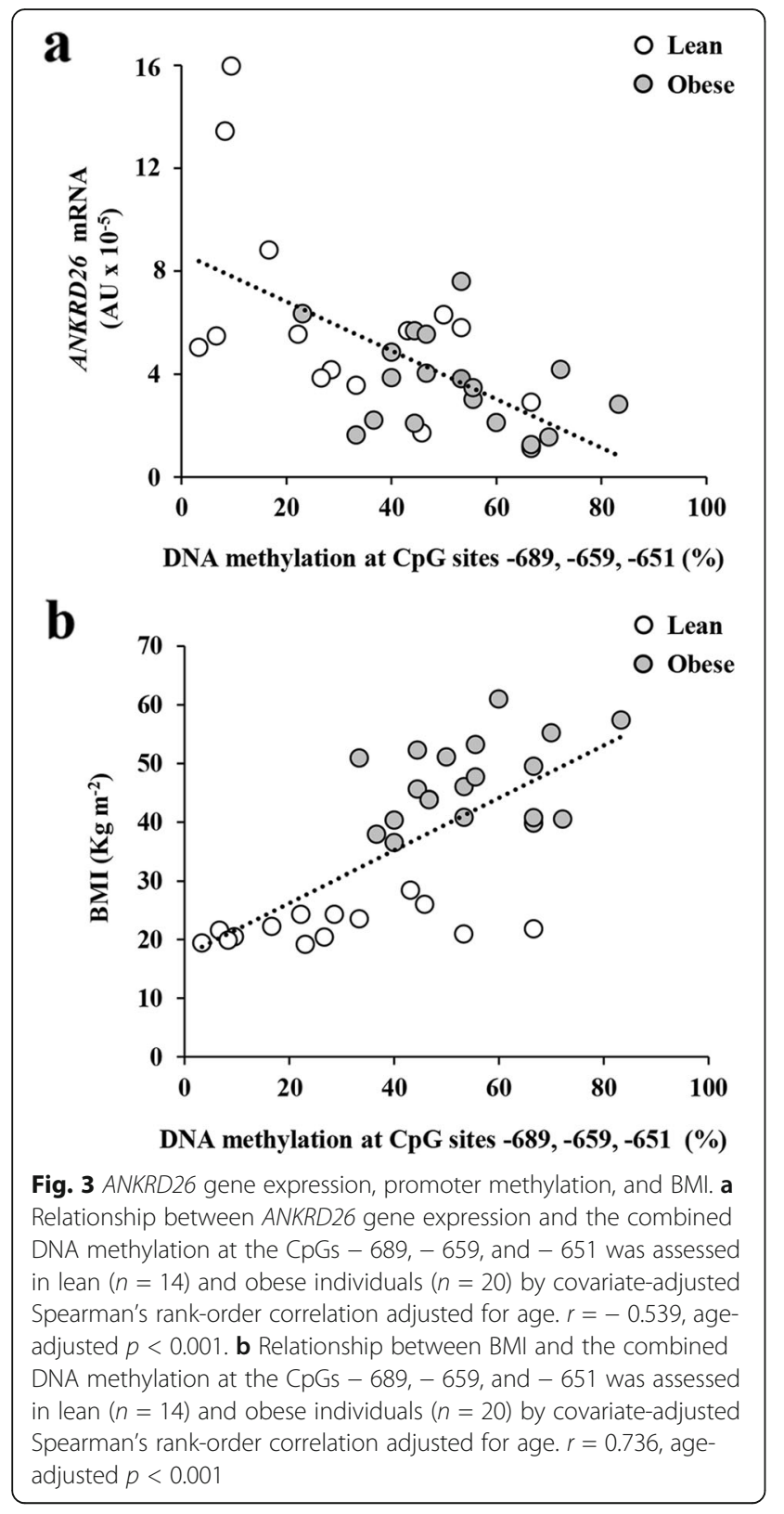

age-adjusted $p=0.002$ ), as well. Interestingly, as also reported in Table 5, the combined DNA methylation levels of the CpG dinucleotides - 689, - 659, and - $651 \mathrm{bp}$ at the ANKRD26 promoter correlated positively to serum TG concentration $(n=34, r=0.593$, age-adjusted $p<0.001$ ) and negatively to serum HDLC concentration ( $n=34, r=-0.539$, age-adjusted $p<$ $0.001)$. Also, the combined methylation of these 3 CpG sites correlate directly to serum levels of CRP ( $n$ $=30, r=0.524$, age-adjusted $p=0.001)$, IL-6 $(n=30, r$ $=0.577$, age-adjusted $p=0.002), \mathrm{IL}-12(n=30, r=$ 0.453 , age-adjusted $p=0.013)$, IL-8 $(n=30, r=0.698$, age-adjusted $p=0.001)$, and RANTES ( $n=30, r=$ 0.514 , age-adjusted $p=0.013)$. Very interestingly,
Table 4 ANKRD26 gene expression in relation to metabolic and inflammatory parameters. Relationship between metabolic or inflammatory parameters and ANKRD26 gene expression was assessed in lean and obese individuals by covariate-adjusted Spearman's rank-order correlation adjusted for age. Number of individuals ( $n$ ), correlation coefficient $r$, and age-adjusted $p$ value are shown in the table. $T G$, triglyceride; $T C$, total cholesterol; $H D L-C$, high-density lipoprotein cholesterol; $L D L-C$, low-density lipoprotein cholesterol; $C R P, C$-reactive protein; IL, interleukin; IFNY, interferon $\gamma ; T N F a$, tumor necrosis factor $a ; I P-10$, interferon gamma-induced protein 10; MCP1, monocyte chemotactic protein 1; MIP1, macrophage inflammatory protein 1; RANTES, regulated on activation, normal $T$ cell expressed, and secreted

\begin{tabular}{|c|c|c|c|}
\hline \multirow[t]{2}{*}{ Parameters } & \multicolumn{3}{|c|}{ Gene expression } \\
\hline & $n$ & $r$ & $p$ value \\
\hline Glucose & 34 & -0.233 & n.s. \\
\hline TG & 34 & -0.630 & $<0.001$ \\
\hline TC & 34 & -0.113 & n.s. \\
\hline HDL-C & 34 & 0.647 & $<0.001$ \\
\hline LDL-C & 34 & -0.315 & n.s. \\
\hline CRP & 34 & -0.494 & 0.001 \\
\hline IL-1 $\beta$ & 30 & -0.498 & 0.010 \\
\hline IL-6 & 30 & -0.401 & 0.027 \\
\hline IL-7 & 30 & -0.185 & n.s. \\
\hline IL-9 & 30 & -0.123 & n.s. \\
\hline IL-12 & 30 & -0.506 & 0.002 \\
\hline IL-17 & 30 & -0.085 & n.s. \\
\hline IFN- $\gamma$ & 30 & -0.112 & n.s. \\
\hline TNF-a & 30 & -0.037 & n.s. \\
\hline |L-8 & 30 & -0.650 & $<0.001$ \\
\hline Eotaxin & 30 & -0.116 & n.s. \\
\hline IP-10 & 30 & -0.520 & 0.002 \\
\hline MCP-1 & 30 & -0.206 & n.s. \\
\hline MIP-1a & 30 & -0.513 & 0.006 \\
\hline MIP-1 $\beta$ & 30 & -0.601 & $<0.001$ \\
\hline RANTES & 30 & -0.476 & 0.002 \\
\hline
\end{tabular}

these relationships were also confirmed when these biochemical and pro-inflammatory parameters were associated to individual $\mathrm{CpG}$ methylation percentages (Additional file 1: Table S2).

\section{Both ANKRD26 mRNA expression and CpG methylation associate with TG/HDL-C ratio}

Interestingly, a negative correlation between the ANKRD26 gene expression and TG/HDL-C ratio was also noted $(n=34, r=-0.728$, age-adjusted $p<0.001$; Fig. 4a). Also, the percentage of $\mathrm{CpG}$ dinucleotides methylation at $-689,-659$, and $-651 \mathrm{bp}$, taken as combined or as individual CpG methylation, of the ANKRD26 promoter positively correlated to the TG/ 
Table 5 Combined DNA methylation at the CpG sites, - 689, 659 , and -651 of the ANKRD26 promoter in relation to metabolic and inflammatory parameters. Relationships were assessed in lean and obese individuals by covariate-adjusted Spearman's rank-order correlation adjusted for age. Number of individuals ( $n$ ), correlation coefficient $r$, and age-adjusted $p$ value are shown on the table. $T G$, triglyceride; $T C$, total cholesterol; $H D L-C$, high-density lipoprotein cholesterol; $L D L-C$, low-density lipoprotein cholesterol; CRP, C-reactive protein; IL, interleukin; IFNY, interferon $\gamma ;$ TNFa, tumor necrosis factor $a ; I P-10$, interferon gamma-induced protein 10; MCP1, monocyte chemotactic protein 1; MIP1, macrophage inflammatory protein 1; RANTES, regulated on activation, normal T cell expressed, and secreted

\begin{tabular}{|c|c|c|c|}
\hline \multirow[t]{2}{*}{ Parameters } & \multicolumn{3}{|c|}{ Combined \% CpG methylation } \\
\hline & $n$ & $r$ & $p$ value \\
\hline Glucose & 34 & 0.081 & n.s. \\
\hline TG & 34 & 0.593 & $<0.001$ \\
\hline TC & 34 & 0.155 & n.s. \\
\hline $\mathrm{HDL}-\mathrm{C}$ & 34 & -0.539 & 0.004 \\
\hline LDL-C & 34 & 0.376 & 0.044 \\
\hline CRP & 34 & 0.524 & 0.001 \\
\hline $\mid L-1 \beta$ & 30 & 0.242 & n.s. \\
\hline IL-6 & 30 & 0.577 & 0.002 \\
\hline IL-7 & 30 & 0.182 & n.s. \\
\hline IL-9 & 30 & 0.032 & n.s. \\
\hline IL-12 & 30 & 0.453 & 0.013 \\
\hline IL-17 & 30 & -0.001 & n.s. \\
\hline IFN- $\gamma$ & 30 & -0.025 & n.s. \\
\hline TNF-a & 30 & -0.083 & n.s. \\
\hline $\mid L-8$ & 30 & 0.698 & 0.001 \\
\hline Eotaxin & 30 & 0.001 & n.s. \\
\hline IP-10 & 30 & 0.337 & n.s. \\
\hline MCP-1 & 30 & 0.305 & n.s. \\
\hline MIP-1a & 30 & 0.333 & 0.050 \\
\hline MIP-1 $\beta$ & 30 & 0.377 & n.s. \\
\hline RANTES & 30 & 0.514 & 0.013 \\
\hline
\end{tabular}

HDL-C ratio ( $n=34, r=0.666$, age-adjusted $p<0.001$; Fig. $4 \mathrm{~b}$ and Additional file 1: Table S2). When the study group subjects were stratified based on the TG/HDL-C ratio [24], we found that, independent of BMI, the ANKRD26 mRNA levels were reduced by about $60 \%$ in the individuals with the TG/HDL-C ratio $>3.0 \mathrm{com}-$ pared with subjects with a TG/HDL-C ratio $<3.0$ (BMIadjusted $p=0.016$; Fig. 4c). Also, DNA methylation at the $-689,-659$, and -651 bp CpG sites was increased by about 2.0-fold (BMI-adjusted $p<0.001$ ), 1.7-fold (BMI-adjusted $p=0.040$ ), and 1.8-fold (BMI-adjusted $p$ $=0.025)$, respectively, in the individuals with a TG/ HDL-C ratio > 3.0 compared with subjects featuring a TG/HDL-C ratio below the cutoff value (Fig. 4d).

\section{Discussion}

The epigenome, at the interface between genome and the environment, undergoes continuous changes through the individual lifetime, which may have major implications to disease susceptibility [7-9]. Consistently, mounting evidence indicates an important role of the epigenetic modifications in determining risk of obesity $[4,33,34]$. Thus, the identification of epigenetic profiles associated with obesity may provide important novel insight into disease pathogenesis, biomarker discovery, and pharmacological targets.

In this report, we have demonstrated that the ANKRD26 gene expression is downregulated in human PBL from obese compared with lean subjects. We also found that the ANKRD26 gene expression in the blood cells correlates positively to its mRNA expression in abdominal VAT, a tissue relevant to ANKRD26 protein function [14, 22, 35, 36], suggesting that perturbation of ANKRD26 expression is biologically relevant to obesity. We also report that (i) hyper-methylation at the CpG dinucleotides - 689, - 659, and - 651 bp from the ANKRD26 TSS occurs in PBL from the obese compared with the lean controls; (ii) a direct cause-effect relationship exists between these methylation events and ANKRD26 gene expression; and (iii) BMI correlates to both gene expression and DNA methylation of the ANKRD26 gene in PBL. Altogether, these findings indicate that hypermethylation at the ANKRD26 promoter and the accompanying downregulation of gene expression are common features of obesity in humans. DNA methylation is the most common and better-characterized epigenetic modification [37, 38]. Evidence in literature also supports the hypothesis that it might also be transgenerationally inherited [39]; however, DNA methylation often occurs in response to environmental variability [40]. Therefore, whether the observed epigenetic downregulation of the ANKRD26 gene precedes or is a consequence of obesity and thus, whether the increased CpG methylation at the $A N K R D 26$ promoter has a role in the regulation of BMI and/or is predictive of obesity onset deserves to be further investigated. Changes in DNA methylation at this gene in humans are consistent with our previous findings in murine models of diet-induced obesity. Indeed, persistence of the high-fat diet regimen and the onset of obesity in mice causes epigenetic silencing of the Ankrd26 mRNA expression due to the specific hyper-methylation of the Ankrd26 promoter at the CpG sites - 436 and - 431 bp [17]. This supports the hypothesis that similar changes of DNA methylation, occurring in the human ANKRD26 gene, might be the result of increased BMI/adiposity typical of obesity. Furthermore, our finding reveal a more pronounced silencing of ANKRD26 and increased 


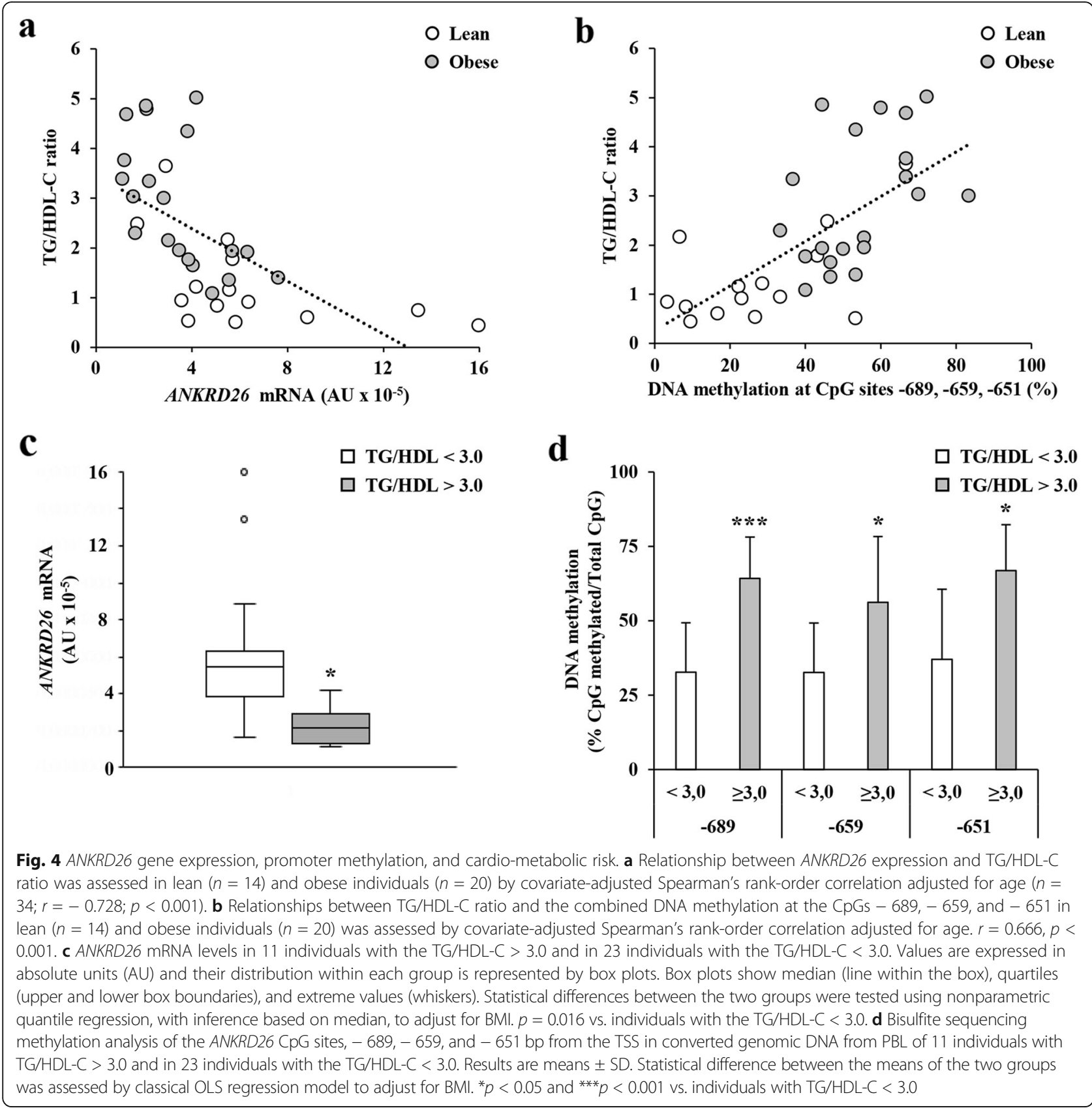

DNA methylation at the - $689 \mathrm{bp}$ CpG in the MUO compared with the MHO individuals. This supports the hypothesis that the epigenetic regulation of the ANKRD26 gene may be sensitive to the alteration of the metabolic and inflammatory profile occurring in the metabolically unhealthy obese [32].

We have further explored the potential clinical relevance of the epigenetic silencing of ANKRD26 by correlating both the ANKRD26 gene expression and DNA methylation to obesity-related endophenotypes. In particular, we have reported that both ANKRD26 mRNA and DNA methylation levels of the CpG dinucleotides -
$689,-659$, and $-651 \mathrm{bp}$, taken as combined or as single CpG methylation percentage, correlate to serum TG and HDL-C concentration. In line with our previous findings in abdominal VAT from obese subjects with normal glucose tolerance [17], we also found that changes of ANKRD26 gene expression and methylation correlate to increased levels of the inflammatory cytokine IL-6, the chemokines IL-8, and RANTES [41], and with CRP, a sensitive marker of low-grade inflammation and cardiometabolic risk in different populations [42-46]. In addition, perturbations of ANKRD26 gene expression and methylation correlate to the TG/HDL-C ratio, a 
recently identified mark of cardio-metabolic risk and of insulin resistance [24-31]. Importantly, stratification of the study group based on the TG/HDL-C index revealed association of higher levels of ANKRD26 methylation and reduced gene expression with high-cardio-metabolic risk, independent of BMI, indicating that alterations of both the DNA methylation and mRNA expression at the $A N K R D 26$ gene correlate to increased risk of insulin resistance and cardiovascular disease in humans.

The major strength of our research design was the use of a site-by-site approach for the investigation of DNA methylation within the ANKRD26 gene promoter/Exon 1 (- 991/+ $390 \mathrm{bp}$ from TSS). This allowed us to (i) screen the cytosine methylation of $92 \mathrm{CpG}$ dinucleotides related to our candidate gene, whose detection, at the best of our knowledge, is only partially covered by commercial DNA methylation arrays and (ii) identify among lean and obese subjects' specific methylation changes at the CpGs, -689 , - 659, and - 651, which are relevant for the ANKRD26 gene expression regulation and are associated with pro-inflammatory and cardio-metabolic risk factors, and which cannot be otherwise discovered. However, some limitations exist in the current study starting from the limited sample size of the recruited individuals. Our findings should be therefore replicated in other large and independent population. Nevertheless, in support of our results, ANKRD26 has been included in a dataset of loci, identified through a whole transcriptbased array, where its gene expression negatively correlated with BMI in a study conducted on the subcutaneous WAT from a male Swedish and Danish discovery cohort $(n=96)$ [47].

\section{Conclusion}

In conclusion, this study demonstrates that downregulation of the ANKRD26 gene caused by promoter hypermethylation at specific CpGs represents a common abnormality in obese patients. These changes correlate to the pro-inflammatory profile and the cardio-metabolic risk factors of the obese individuals, suggesting they mark the adverse health outcome occurring in some of these patients.

\section{Methods}

\section{Subject enrollment, sampling, and management Subject enrollment}

Thirty-four individuals, 14 lean $(7$ males and $7 \mathrm{fe}-$ males) undergoing cholecystectomy and 20 obese (10 males and 10 females) undergoing sleeve gastrectomy, were recruited at the Federico II University of Naples, and defined, respectively, based on BMI $<25 \mathrm{~kg} \mathrm{~m}^{-2}$ and BMI $\geq 30 \mathrm{~kg} \mathrm{~m}^{-2}$ [48]. Participants were selected as follows. Inclusion criteria are as follows: age between 25 and 50 years and Caucasian ethnicity.
Exclusion criteria are as follows: not knowledge of a verifiable medical treatment period; psychotic disorders; severe depression; personality and eating behavior disorders assessed by a dedicated psychiatrist or psychologist; alcoholism and drug addiction; diseases related to reduced life expectancy; inability to take care of him/herself; inadequate family and social support; obesity secondary to endocrinopathies; gastrointestinal inflammatory diseases; risk of upper gastrointestinal tract bleeding; previous or current tumors; and use of drugs that can influence epigenetic status. The study adhered to the Code of Ethics of the World Medical Association (Declaration of Helsinki) and has been reviewed and approved by the Ethic Committee of the Federico II University of Naples (Ethics Approval Number: No. 254/17). Informed consent was obtained individually from all of the subjects enrolled in the study. Obese subjects have been also classified as MHO or MUO based on Wildman et al. [32]. In particular, MUO is defined in subjects by the presence of two or more of these 6 criteria: blood pressure systolic $\geq 130 \mathrm{mmHg}$ and/or diastolic $\geq 85 \mathrm{mmHg}$ or use of anti-hypertensive drugs; fasting triglycerides $\geq 150 \mathrm{mg} \mathrm{dL}^{-1}$ or use of lipid-lowering drugs; fasting HDL-C $\leq 40 \mathrm{mg} \mathrm{dL}^{-1}$ in men and $\leq 50$ $\mathrm{mg} \mathrm{dL}^{-1}$ in women or use of lipid-lowering drugs; fasting glucose $\geq 100 \mathrm{mg} \mathrm{dL}^{-1}$ or use of anti-diabetic drugs; homeostatic model assessment of insulin resistance (HOMA-IR) $>90^{\text {th }}$ percentile; and CRP $>90^{\text {th }}$ percentile, while MHO subjects are defined by the presence of 0 or 1 of the previous criteria.

\section{Sampling and management}

Blood and sera samples were collected from fasted patients the day before surgery, and successively handled, processed, and stored by the same investigator. In detail, 1 whole blood vacuum tube was collected from each subject (lean, $n=14$; obese, $n=20$ ) enrolled in the study for PBL isolation. Also, 1 serum vacuum tube was collected from each subject (lean, $n=14$; obese, $n=20$ ) enrolled in the study for the determination of biochemical parameters, while a further serum vacuum tube was collected from 30 patients out of 34 for the determination of inflammatory parameters through Bioplex multiplex analysis. Blood cell count was evaluated for each individual patient and no significant differences were reported within subjects. PBL isolation was performed on each sample by using the following procedure. Whole blood samples were incubated on ice for 15 min with 5 volume of erythrocyte lysis buffer $\left(\mathrm{KHCO}_{3} 10 \mathrm{mM}, \mathrm{NH}_{4} \mathrm{Cl} 155\right.$ $\mathrm{mM}$, EDTA $0.1 \mathrm{mM}$ ), and PBL was recovered by centrifugation at $400 \times g$ for $10 \mathrm{~min}$, and then stored at $-80^{\circ} \mathrm{C}$ in RNA Later stabilization reagent (Qiagen, Hilden, Germany). At the end of the recruitment, PBL obtained 
from each patient were lysed in RLT buffer $1 \times$ and total RNA and genomic DNA were then isolated using the AllPrep DNA/RNA/miRNA Universal kit (Qiagen) and following the manufacturer's instructions.

\section{Abdominal VAT sampling}

Abdominal VAT biopsies were collected from 10 of the recruited patients (5 lean and 5 obese) and were handled and stored by the same investigator. In detail, biopsies were snap frozen in liquid nitrogen, and then stored at $80^{\circ} \mathrm{C}$ in RNA Later stabilization reagent (Qiagen). At the end of the recruitment, VAT biopsies were homogenized in RLT buffer $1 \times$ by using the Tissue Lyser LT bead mill (Qiagen), and total RNA was then isolated using the AllPrep DNA/RNA/miRNA Universal kit (Qiagen) and following the manufacturer's instructions.

\section{Determination of biochemical and inflammatory parameters}

Plasma glucose and serum levels of TC, HDL-C, LDL-C, TG, and CRP were determined with an ABX Pentra 400 (Horiba Ltd., Kyoto, Japan). Serum samples have been also used for the dosage of the following secreted inflammatory mediators by Bioplex multiplex Human Cytokine, Chemokine and Growth factor kit (Bio-Rad Laboratories, Hercules, CA): IL-1 $\beta$, IL-6, IL-7, IL-9, IL12, IL-17, Interferon $\gamma$ (IFN $\gamma$ ), tumor necrosis factor $\alpha$ (TNF $\alpha$ ), IL-8, eotaxin, IP-10, MCP1, MIP1 $\alpha$, MIP1 $\beta$, and RANTES.

\section{Quantitative real-time PCR}

cDNA synthesis was performed from total RNA $(1 \mu \mathrm{g})$ isolated from PBL samples or from abdominal VAT biopsies by using the SuperScript ${ }^{\mathrm{TM}}$ III Reverse Transcriptase (Thermo Fisher Scientific, Waltham, MA) and following the manufacturer's instructions. cDNA from each sample was then used as a template for quantitative real-time PCR assays. In detail, for each sample, reactions were performed in triplicates using iQ SYBR Green Supermix on an iCycler real-time detection system (Bio-Rad Laboratories) by using the following cycling condition and reaction protocol. Cycling condition: $10 \mathrm{~min}$ at $95^{\circ} \mathrm{C}$ for 1 cycle, and $15 \mathrm{~s}$ at $95^{\circ} \mathrm{C}$ and $1 \mathrm{~min}$ at $60^{\circ} \mathrm{C}$ repeated for 40 cycles. Reaction protocol: cDNA (25 ng), forward and reverse PCR primers (200 nM each), iQ SYBR Green Supermix $1 \mathrm{X}$ (Bio-rad laboratories) in a final volume of $10 \mu \mathrm{L}$. The absolute quantification of the hsANKRD26 mRNA expression levels for each sample was carried out by using hs $28 S$ ribosomal RNA, as control reference [49]. hs28S ribosomal RNA has been selected as reference gene upon a comparison with other three reference genes of the threshold cycle (Ct) variability (Additional file 1: Table S3). The following standard curves were used for the calculations: hsANKRD26 standard curve, $y=-3.661 \times+36.554, r=$
0.9995, and hs28S standard curve, $y=-3.587 x+36.164$, $r=0.9990$. Primer sequences were as follow: hs $28 S$ F: $5^{\prime}-$ cccagtgctctgaatgtcaa-3'; hs28S R: 5' -agtgggaatctcgttcatcc3'; hs ANKRD26 F: 5'-gtatgctagtagtggtcctgc-3'; and hs $A N K R D 26$ R: $5^{\prime}$-gtaggccttccttcatcctcat-3'.

\section{DNA methylation analysis by bisulfite conversion}

Genomic DNA from PBL and from abdominal VAT biopsies was prepared as described above. Bisulfite treatment of 350 ng of genomic DNA for each sample was converted with the EZ DNA Methylation Kit (Zymo Research, Orange, CA), following the manufacturer's instructions. For the analysis, ANKRD26 promoter was divided as follows: S1, - 786/- 722 bp; S2, - 716/- 370 bp; S3, - 349/- 48 bp; S4, - 68/+ 147 bp; and $55,+134 /+390$ bp from TSS. Bisulfite-converted genomic DNA was amplified by PCR using specific primers for each site. The PCR fragments were then cloned into the pGEM T-Easy vector system (Promega, Madison, WI). Bisulfite genomic sequencing was performed as previously reported [50]. In detail, to determine methylation status, 10 clones for each sample were sequenced on AB 3500 genetic analyzer (Life Technologies, Carlsbad, CA). The percentage of individual methylation and the percentage of combined methylation at the CpGs - 689, - 659, and - 651 were calculated using the following two formulas: individual methylation $\%=\left(\mathrm{CpG}\right.$ methylated. $\mathrm{CpG}$ total $\left.^{-1}\right) \times 100$; combined methylation $\%=(\%$ methylation of CpG $-689+\%$ methylation of $\mathrm{CpG}-659+\%$ methylation of CpG - 651)/3. Primers sequences: ANKRD26 S1 F: 5 '-gtaattttgttgagattttatttga-3', ANKRD26 S1 R: 5'-actacaatctccacctcctaaactc-3', ANKRD26 S2 F: 5' -agtttaggaggtggagattgtagtg-3', ANKRD26 S2 F: 5'-acaaatacaacaacaaaaaacacaaa-3', ANKRD26 S3 F: 5' gtatttaaagggatatggaaggg-3', ANKRD26 S3 R: 5'-cccaataatcaaatatactccatac-3', ANKRD26 S4 F: 5' -tggagtatattgattattgggtttt-3', ANKRD26 S4 R: 5'-aacttcaaaaacacctcatat ctctct-3', ANKRD26 S5 F: 5' -agagagatatgaggtgttttgaagtt-3', ANKRD26 S5 R: 5'-caaaccattcttcctaaacaaaaaa-3'. Bioinformatics analysis was carried out using EMBOSS CpGplot (available from www.ebi.ac.uk/Tools/seqstats/emboss cpgplot/; accessed November 2015).

\section{Cloning, in vitro methylation, and luciferase assay}

ANKRD26 promoter (- 716/- 597 bp) was amplified by PCR. The purified PCR fragment was cloned into the firefly luciferase reporter pCpG-free-promoter-Lucia vector (Invivogen, Toulouse, France). This vector is completely void of $\mathrm{CpG}$ dinucleotides in all the elements required for replication and selection of the plasmid in E. coli and gene expression in mammalian cells. Also, it is devoid of all Dam methylation sites (GATC) to prevent prokaryotic methylation [51]. The pCpG-Ankrd26 vector was amplified in E. coli GT115 cells (Invivogen). In vitro methylation was performed using the M.SssI CpG methyltransferase following manufacturer's protocol (New 
England BioLabs, Ipswich, MA). Un-methylated DNA was obtained in the absence of M.SssI. Methylation was confirmed by digestion with MspJI (New England BioLabs). HEK-293 cells were transfected with the CpG methylated or un-methylated pCpG-ANKRD26 vector and Renilla control vector (Promega, Madison WI) by lipofectamine (Life Technologies), following manufacturer's instructions. Firefly luciferase activity of each transfection was normalized for transfection efficiency against Renilla luciferase activity.

\section{Sample size}

Sample sizes were calculated by using the G*Power 3.1.9.2 software (Heinrich-Heine-Universität Düsseldorf, Germany) [52]. In detail, a sample size of 34 participants, $n=20$ for obese (group 1) and $n=14$ for lean (group 2), achieved $95 \%$ power to detect a difference of $-39 \times$ $10^{-5}$ between the null hypothesis that both group means are equal to $159 \times 10^{-5}$ and the alternative hypothesis that the mean of group 2 is different and equal to $198 \times$ $10^{-5}$, considering a two-sample $t$ test, a significance level $(\alpha)$ of 0.05 , an estimated group standard deviations of 38 $\times 10^{-5}$ and $18 \times 10^{-5}$, and an allocation ratio $\mathrm{N} 2 / \mathrm{N} 1=$ 1.4. For calculations, values of the Ankrd26 mRNA (mean $\pm \mathrm{SD}$ ) in obese and lean mice were applied [17]. Information about ANKRD26 mRNA levels in humans, to the best of our knowledge, was not available. A 1.4 allocation ratio $\mathrm{N} 2 / \mathrm{N} 1$ was decided based on the prediction of a $40 \%$ larger recruitment of obese versus lean individuals.

\section{Statistical and experimental procedures Statistical procedures}

For symmetrically distributed variables, data are shown as mean $\pm \mathrm{SD}$, while for skewed distributions, data are presented as median (first quartile-Q1; third quartileQ3). Statistical differences between groups were tested using parametric or nonparametric method, as appropriate. Two-tailed unpaired Student's $t$ test, or classical OLS regression model to adjust for potential confounders, was used as parametric methods, while MannWhitney $U$ test, or quantile regression model with inference based on median to adjust for potential confounders, was used as nonparametric methods. For luciferase assay, comparison between groups was determined by one-way analysis of variance (ANOVA) and Bonferroni correction post hoc tests were carried out to detect significant differences between specific groups. Relationships between variables were assessed through an extension of Spearman's rank correlations [53], which also allowed to adjusted correlations for age using probability-scale residuals. For all the statistical tests, $p<$ 0.05 was considered statistically significant. $R$ software environment for statistical computing, Version 3.6.0
(http://www.R-project.org), was used for all statistical analysis.

\section{Experimental procedures}

For each reported investigation, the experiments have been performed always by the same investigator. Same batch reagents and same instruments have been used. Technical and biological replicates were also considered in order to exclude technical errors and biological variance. Controls for each group of experiments have been also used.

\section{Supplementary information}

Supplementary information accompanies this paper at https://doi.org/10. 1186/s13148-019-0768-0.

Additional file 1: Figure S1. Correlation between VAT and PBL ANKRD26 mRNA. Table S1. DNA methylation enrichment in the ANKRD26 promoter. Table S2. Individual DNA methylation at the CpG sites, -689, -659 , and -651 of the ANKRD26 promoter in relation to ANKRD26 mRNA expression and to anthropometric, metabolic and inflammatory parameters. Table S3. Reference gene's threshold cycle $(\mathrm{Ct})$ variability in lean and obese individuals.

\section{Abbreviations}

ANKRD26: Ankyrin Repeat Domain 26; ANOVA: One-way analysis of variance; BMI: Body mass index; CRP: C-reactive protein; CVDs: Cardiovascular diseases; HbA1c: Hemoglobin A1c; HDL-C: High-density lipoprotein cholesterol; HOMA-IR: Homeostatic model assessment of insulin resistance;

IFNY: Interferon Y; IL: Interleukin; IP-10: Interferon gamma-induced protein; LDL-C: Low-density lipoprotein cholesterol; MAF: Minor allele frequency; MCP1: Monocyte chemotactic protein 1; MeDIP-seq: Methylated DNA immuno-precipitation sequencing; MHO: Metabolically healthy obese; MIP1: Macrophage inflammatory protein 1; MUO: Metabolically unhealthy obese; PBL: Peripheral blood leukocytes; RANTES: Normal T cell expressed and secreted; SNPS: Single-nucleotide polymorphisms; T2D: Type 2 diabetes; TC: Total cholesterol; TG: Triglycerides; TNFa: Tumor necrosis factor a; VAT: Visceral adipose tissue

\section{Acknowledgements}

We thank Mrs. Maria Peluso and Mrs. Giulia Speranza for administrative support and Mr Said Maouali for technical support.

\section{Authors' contributions}

Conceptualization and formal analysis were done by $A D, M L$, and $L P$. Investigation was done by $A D, M L, L P, M C, G C, S D S, R S, F Z$, and SC. Resources were provided by $M M$ and $F B$. Writing original draft preparation was done by $A D, M L$, and LP. Statistical analysis was done by PD. Editing and writing review were done by PD, MM, PF, CM, FB, and GAR. Visualization was done by CM. Supervision was done by GAR. Project administration was done by FB. Funding acquisition was done by PF, CM, FB, and GAR. All authors read and approved the definitive version of the manuscript.

\section{Funding}

This study was funded, in part, by the Ministero dell'Istruzione, Università e della Ricerca Scientifica (grants PRIN 2015 and PRIN 2017), by the Regione Campania (POR FESR 2014-2020 - Obiettivo specifico 1.2. - Manifestazione di Interesse per la Realizzazione di Technology Platform nell'ambito della Lotta alle Patologie Oncologiche" - Projects COEPICA, RARE PLAT NET, and SATIN), by the Italian Diabete Ricerca Foundation and Eli Lilly Italy (2018-2020), by the European Foundation for the Study of Diabetes (EFSD)/Boehringer Ingelheim (2018-2020).

\section{Availability of data and materials}

The data sets used and/or analysed during this study are available from the corresponding authors on reasonable request. 


\section{Ethics approval and consent to participate}

The study adhered to the Code of Ethics of the World Medical Association (Declaration of Helsinki) and has been reviewed and approved by the Ethic Committee of the Federico II University of Naples (Ethics Approval Number: No. 254/17). Informed consent was obtained individually from all of the subjects enrolled in the study.

\section{Consent for publication}

Not applicable.

\section{Competing interests}

The authors declare that they have no competing interests.

\section{Author details}

'URT Genomics of Diabetes, Institute of Experimental Endocrinology and Oncology, National Research Council, Via Pansini 5, 80131 Naples, Italy. ${ }^{2}$ Department of Translational Medicine, Federico II University of Naples, Via Pansini 5, 80131 Naples, Italy. ${ }^{3}$ Department of Public Health, Federico II University of Naples, Via Pansini 5, 80131 Naples, Italy. ${ }^{4}$ Department of Clinical Medicine and Surgery, Federico II University of Naples, Via Pansini 5 , 80131 Naples, Italy.

\section{Received: 28 May 2019 Accepted: 21 October 2019}

Published online: 04 December 2019

\section{References}

1. NCD Risk Factor Collaboration (NCD-RisC). Trends in adult body-mass index in 200 countries from 1975 to 2014: a pooled analysis of 1698 populationbased measurement studies with 19.2 million participants. Lancet. 2016. https://doi.org/10.1016/S0140-6736(16)30054-X.

2. Williams EP, Mesidor M, Winters K, Dubbert PM, Wyatt SB. Overweight and obesity: prevalence, consequences, and causes of a growing public health problem. Curr Obes Rep. 2015. https://doi.org/10.1007/s13679-015-0169-4.

3. González-Muniesa P, Mártinez-González MA, Hu FB, Després JP, Matsuzawa Y, Loos RJF, Moreno LA, Bray GA, Martinez JA. Obesity. Nat Rev Dis Primers. 2017. https://doi.org/10.1038/nrdp.2017.34.

4. Drong AW, Lindgren CM, McCarthy MI. The genetic and epigenetic basis of type 2 diabetes and obesity. Clin Pharmacol Ther. 2012. https://doi.org/10. 1038/clpt.2012.149.

5. Rask-Andersen M, Karlsson T, Ek WE, Johansson Å. Gene-environment interaction study for BMI reveals interactions between genetic factors and physical activity, alcohol consumption and socioeconomic status. PLoS Genet. 2017. https://doi.org/10.1371/journal.pgen.1006977.

6. Li S, Zhao JH, Luan J, Ekelund U, Luben RN, Khaw KT, Wareham NJ, Loos RJ. Physical activity attenuates the genetic predisposition to obesity in 20,000 men and women from EPIC-Norfolk prospective population study. PLoS Med. 2010. https://doi.org/10.1371/journal.pmed.1000332.

7. Jirtle RL, Skinner MK. Environmental epigenomics and disease susceptibility. Nat Rev Genet. 2007:8(4):253-62.

8. Ho SM, Johnson A, Tarapore $P$, Janakiram V, Zhang X, Leung YK Environmental epigenetics and its implication on disease risk and health outcomes. ILAR J. 2012. https://doi.org/10.1093/ilar.53.3-4.289.

9. Desiderio A, Spinelli R, Ciccarelli M, Nigro C, Miele C, Beguinot F, Raciti GA. Epigenetics: spotlight on type 2 diabetes and obesity. J Endocrinol Invest. 2016. https://doi.org/10.1007/s40618-016-0473-1.

10. Kwon EJ, You YA, Park B, Ha EH, Kim HS, Park H, Kim YJ. Association between the DNA methylations of POMC, MC4R, and HNF4A and metabolic profiles in the blood of children aged 7-9 years. BMC Pediatr. 2018. https:// doi.org/10.1186/s12887-018-1104-0.

11. Dick KJ, Nelson CP, Tsaprouni L, Sandling JK, Aïssi D, Wahl S, Meduri E, Morange PE, Gagnon F, Grallert H, Waldenberger M, Peters A, Erdmann J, Hengstenberg C, Cambien F, Goodall AH, Ouwehand WH, Schunkert H, Thompson JR, Spector TD, Gieger C, Trégouët DA, Deloukas P, Samani NJ. DNA methylation and body-mass index: a genome-wide analysis. Lancet. 2014. https://doi.org/10.1016/S0140-6736(13)62674-4.

12. Kuehnen P, Mischke M, Wiegand S, Sers C, Horsthemke B, Lau S, Keil T, Lee YA, Grueters A, Krude H. An Alu element-associated hypermethylation variant of the POMC gene is associated with childhood obesity. PLoS Genet. 2012. https://doi.org/10.1371/journal.pgen.1002543.

13. Pfeiffer S, Krüger J, Maierhofer A, Böttcher Y, Klöting N, El Hajj N, Schleinitz D, Schön MR, Dietrich A, Fasshauer M, Lohmann T, Dreßler M, Stumvoll M,
Haaf T, Blüher M, Kovacs P. Hypoxia-inducible factor $3 \mathrm{~A}$ gene expression and methylation in adipose tissue is related to adipose tissue dysfunction Sci Rep. 2016. https://doi.org/10.1038/srep27969.

14. Mendelson MM, Marioni RE, Joehanes R, Liu C, Hedman ÅK, Aslibekyan S, Demerath EW, Guan W, Zhi D, Yao C, Huan T, Willinger C, Chen B, Courchesne P, Multhaup M, Irvin MR, Cohain A, Schadt EE, Grove ML, Bressler J, North K, Sundström J, Gustafsson S, Shah S, AF MR, Harris SE, Gibson J, Redmond P, Corley J, Murphy L, Starr JM, Kleinbrink E, Lipovich L, Visscher PM, Wray NR, Krauss RM, Fallin D, Feinberg A, Absher DM, Fornage M, Pankow JS, Lind L, Fox C, Ingelsson E, Arnett DK, Boerwinkle E, Liang L, Levy D, Deary IJ. Association of body mass index with DNA methylation and gene expression in blood cells and relations to cardiometabolic disease: a Mendelian randomization approach. PLoS Med. 2017. https://doi.org/10. 1371/journal.pmed.1002215.

15. Wahl S, Drong A, Lehne B, Loh M, Scott WR, Kunze S, Tsai PC, Ried JS, Zhang W, Yang Y, Tan S, Fiorito G, Franke L, Guarrera S, Kasela S, Kriebel J, Richmond RC, Adamo M, Afzal U, Ala-Korpela M, Albetti B, Ammerpohl O, Apperley JF, Beekman M, Bertazzi PA, Black SL, Blancher C, Bonder MJ, Brosch $M$, Carstensen-Kirberg M, de Craen AJ, de Lusignan S, Dehghan A, Elkalaawy M, Fischer K, Franco OH, Gaunt TR, Hampe J, Hashemi M, Isaacs A, Jenkinson A, Jha S, Kato N, Krogh V, Laffan M, Meisinger C, Meitinger T, Mok ZY, Motta V, Ng HK, Nikolakopoulou Z, Nteliopoulos G, Panico S, Pervjakova N, Prokisch H, Rathmann W, Roden M, Rota F, Rozario MA, Sandling JK, Schafmayer C, Schramm K, Siebert R, Slagboom PE, Soininen P, Stolk L, Strauch K, Tai ES, Tarantini L, Thorand B, Tigchelaar EF, Tumino R, Uitterlinden $A G$, van Duijn $C$, van Meurs JB, Vineis $P$, Wickremasinghe $A R$, Wijmenga C, Yang TP, Yuan W, Zhernakova A, Batterham RL, Smith GD, Deloukas P, Heijmans BT, Herder C, Hofman A, Lindgren CM, Milani L, van der Harst $P$, Peters $A$, Illig $T$, Relton $C L$, Waldenberger $M$, Järvelin MR, Bollati $V$, Soong R, Spector TD, Scott J, McCarthy MI, Elliott P, Bell JT, Matullo G, Gieger C, Kooner JS, Grallert H, Chambers JC. Epigenome-wide association study of body mass index, and the adverse outcomes of adiposity. Nature. 2017;541(7635):81-6. https://doi.org/10.1038/nature20784.

16. Parrillo L, Costa V, Raciti GA, Longo M, Spinelli R, Esposito R, Nigro C, Vastolo V, Desiderio A, Zatterale F, Ciccodicola A, Formisano P, Miele C, Beguinot F. Hoxa5 undergoes dynamic DNA methylation and transcriptional repression in the adipose tissue of mice exposed to high-fat diet. Int J Obes (Lond). 2016. https://doi.org/10.1038/ijo.2016.36.

17. Raciti GA, Spinelli R, Desiderio A, Longo M, Parrillo L, Nigro C, D’Esposito V, Mirra P, Fiory F, Pilone V, Forestieri P, Formisano P, Pastan I, Miele C, Beguinot F. Specific CpG hyper-methylation leads to Ankrd26 gene downregulation in white adipose tissue of a mouse model of diet-induced obesity. Sci Rep. 2017. https://doi.org/10.1038/srep43526.

18. Dong C, Li WD, Geller F, Lei L, Li D, Gorlova OY, Hebebrand J, Amos Cl, Nicholls RD, Price RA. Possible genomic imprinting of three human obesityrelated genetic loci. Am J Hum Genet. 2005;76(3):427-37.

19. Mariman EC, Vink RG, Roumans NJ, Bouwman FG, Stumpel CT, Aller EE, van Baak MA, Wang P. The cilium: a cellular antenna with an influence on obesity risk. Br J Nutr. 2016. https://doi.org/10.1017/S0007114516002282.

20. He L, Kernogitski Y, Kulminskaya I, Loika Y, Arbeev KG, Loiko E, Bagley O, Duan M, Yashkin A, Ukraintseva SV, Kovtun M, Yashin Al, Kulminski AM. Pleiotropic meta-analyses of longitudinal studies discover novel genetic variants associated with age-related diseases. Front Genet. 2016;7:179.

21. Bera TK, Liu XF, Yamada M, Gavrilova O, Mezey E, Tessarollo L, Anver M, Hahn Y, Lee B, Pastan I. A model for obesity and gigantism due to disruption of the Ankrd26 gene. Proc Natl Acad Sci U S A. 2008;105(1): 270-5.

22. Raciti GA, Bera TK, Gavrilova O, Pastan I. Partial inactivation of Ankrd26 causes diabetes with enhanced insulin responsiveness of adipose tissue in mice. Diabetologia. 2011. https://doi.org/10.1007/s00125-011-2263-9.

23. Acs P, Bauer PO, Mayer B, Bera T, Macallister R, Mezey E, Pastan I. A novel form of ciliopathy underlies hyperphagia and obesity in Ankrd26 knockout mice. Brain Struct Funct. 2015. https://doi.org/10.1007/s00429-014-0741-9.

24. Marotta T, Russo BF, Ferrara LA. Triglyceride-to-HDL-cholesterol ratio and metabolic syndrome as contributors to cardiovascular risk in overweight patients. Obesity (Silver Spring). 2010. https://doi.org/10.1038/oby.2009.446.

25. Salazar MR, Carbajal HA, Espeche WG, Leiva Sisnieguez CE, Balbín E, Dulbecco CA, Aizpurúa M, Marillet AG, Reaven GM. Relation among the plasma triglyceride/high-density lipoprotein cholesterol concentration ratio, insulin resistance, and associated cardio-metabolic risk factors in men and women. Am J Cardiol. 2012. https://doi.org/10.1016/j.amjcard.2012.02.016. 
26. Iwani NA, Jalaludin MY, Zin RM, Fuziah MZ, Hong JY, Abqariyah Y, Mokhtar $\mathrm{AH}$, Wan Nazaimoon WM. Triglyceride to HDL-C ratio is associated with insulin resistance in overweight and obese children. Sci Rep. 2017. https:// doi.org/10.1038/srep40055.

27. Yang SH, Du Y, Li XL, Zhang Y, Li S, Xu RX, Zhu CG, Guo YL, Wu NQ, Qing P, Gao Y, Cui CJ, Dong Q, Sun J, Li JJ. Triglyceride to high-density lipoprotein cholesterol ratio and cardiovascular events in diabetics with coronary artery disease. Am J Med Sci 2017; doi: https://doi.org/10.1016/j.amjms.2017.03.032.

28. da Luz PL, Favarato D, Faria-Neto JR Jr, Lemos P, Chagas AC. High ratio of triglycerides to $\mathrm{HDL}$-cholesterol predicts extensive coronary disease. Clinics (Sao Paulo). 2008:63(4):427-32.

29. Ren X, Chen ZA, Zheng S, Han T, Li Y, Liu W, Hu Y. Association between triglyceride to $\mathrm{HDL}-\mathrm{C}$ ratio (TG/HDL-C) and insulin resistance in Chinese patients with newly diagnosed type 2 diabetes mellitus. PLoS One. 2016. https://doi.org/10.1371/journal.pone.0154345.

30. Quispe R, Martin SS, Jones SR. Triglycerides to high-density lipoproteincholesterol ratio, glycemic control and cardiovascular risk in obese patients with type 2 diabetes. Curr Opin Endocrinol Diabetes Obes. 2016. https://doi. org/10.1097/MED.0000000000000241.

31. Musso C, Graffigna M, Soutelo J, Honfi M, Ledesma L, Miksztowicz V, Pazos M, Migliano M, Schreier LE, Berg GA. Cardiometabolic risk factors as apolipoprotein B, triglyceride/HDL-cholesterol ratio and C-reactive protein, in adolescents with and without obesity: cross-sectional study in middle class suburban children. Pediatr Diabetes. 2011. https://doi.org/10.1111/j. 1399-5448.2010.00710.x.

32. Wildman RP, Muntner P, Reynolds K, McGinn AP, Rajpathak S, Wylie-Rosett J, Sowers MR. The obese without cardiometabolic risk factor clustering and the normal weight with cardiometabolic risk factor clustering: prevalence and correlates of 2 phenotypes among the US population (NHANES 19992004). Arch Intern Med. 2008. https://doi.org/10.1001/archinte.168.15.1617.

33. van Dijk SJ, Tellam RL, Morrison JL, Muhlhausler BS, Molloy PL. Recent developments on the role of epigenetics in obesity and metabolic disease. Clin Epigenetics. 2015. https://doi.org/10.1186/s13148-015-0101-5.

34. van Vliet-Ostaptchouk JV, Snieder H, Lagou V. Gene-lifestyle interactions in obesity. Curr Nutr Rep. 2012;1:184-96.

35. Fei Z, Bera TK, Liu X, Xiang L, Pastan I. Ankrd26 gene disruption enhances adipogenesis of mouse embryonic fibroblasts. J Biol Chem. 2011;286(31): 27761-8. https://doi.org/10.1074/jbc.M111.248435.

36. Liu XF, Bera TK, Kahue C, Escobar T, Fei Z, Raciti GA, Pastan I. ANKRD26 and its interacting partners TRIO, GPS2, HMMR and DIPA regulate adipogenesis in 3 T3-L1 cells. PLoS One. 2012. https://doi.org/10.1371/journal.pone. 0038130 .

37. Robertson KD. DNA methylation and human disease. Nat Rev Genet. 2005; 6(8):597-610.

38. Jin B, Li Y, Robertson KD. DNA methylation: superior or subordinate in the epigenetic hierarchy? Genes Cancer. 2011. https://doi.org/10.1177/ 1947601910393957.

39. Heard E, Martienssen RA. Transgenerational epigenetic inheritance: myths and mechanisms. Cell. 2014. https://doi.org/10.1016/j.cell.2014.02.045.

40. Heijmans BT, Tobi EW, Stein AD, Putter H, Blauw GJ, Susser ES, Slagboom PE, Lumey LH. Persistent epigenetic differences associated with prenatal exposure to famine in humans. Proc Natl Acad Sci U S A. 2008. https://doi. org/10.1073/pnas.0806560105.

41. Turner MD, Nedjai B, Hurst T, Pennington DJ. Cytokines and chemokines: at the crossroads of cell signalling and inflammatory disease. Biochim Biophys Acta. 2014. https://doi.org/10.1016/j.bbamcr.2014.05.014.

42. Onat A, Can G, Hergenç G. Serum C-reactive protein is an independent risk factor predicting cardiometabolic risk. Metabolism. 2008;57(2):207-14. https://doi.org/10.1016/j.metabol.2007.09.002.

43. Emerging Risk Factors Collaboration, Kaptoge S, Di Angelantonio E, Lowe G, Pepys MB, Thompson SG, Collins R, Danesh J. C-reactive protein concentration and risk of coronary heart disease, stroke, and mortality: an individual participant meta-analysis. Lancet. 2010. https://doi.org/10.1016/ S0140-6736(09)61717-7.

44. Ellulu MS, Patimah I, Khaza'ai H, Rahmat A, Abed Y. Obesity and inflammation: the linking mechanism and the complications. Arch Med Sci. 2017. https://doi.org/10.5114/aoms.2016.58928.

45. Aronson D, Bartha P, Zinder O, Kerner A, Markiewicz W, Avizohar O, Brook GJ, Levy Y. Obesity is the major determinant of elevated C-reactive protein in subjects with the metabolic syndrome. Int J Obes Relat Metab Disord. 2004;28(5):674-9.
46. Kahn SE, Zinman B, Haffner SM, O'Neill MC, Kravitz BG, Yu D, Freed MI, Herman WH, Holman RR, Jones NP, Lachin JM, Viberti GC, ADOPT Study Group. Obesity is a major determinant of the association of C-reactive protein levels and the metabolic syndrome in type 2 diabetes. Diabetes. 2006;55(8):2357-64.

47. Rönn $T$, Volkov $P$, Gillberg $L$, Kokosar M, Perfilyev $A$, Jacobsen $A L$, Jørgensen SW, Brøns C, Jansson PA, Eriksson KF, Pedersen O, Hansen T, Groop L, Stener-Victorin E, Vaag A, Nilsson E, Ling C. Impact of age, BMI and HbA1C levels on the genome-wide DNA methylation and mRNA expression patterns in human adipose tissue and identification of epigenetic biomarkers in blood. Hum Mol Genet. 2015. https://doi.org/10.1093/hmg/ ddv124.

48. Obesity and overweight - World Health Organization. https://www.who.int/ news-room/fact-sheets/detail/obesity-and-overweight. Accessed 16 Feb 2018.

49. Thellin O, Zorzi W, Lakaye B, De Borman B, Coumans B, Hennen G, Grisar T, Igout A, Heinen E. Housekeeping genes as internal standards: use and limits. J Biotechnol. 1999;75(2-3):291-5.

50. Longo M, Raciti GA, Zatterale F, Parrillo L, Desiderio A, Spinelli R, Hammarstedt A, Hedjazifar S, Hoffmann JM, Nigro C, Mirra P, Fiory F, Formisano P, Miele C, Smith U, Beguinot F. Epigenetic modifications of the Zfp/ZNF423 gene control murine adipogenic commitment and are dysregulated in human hypertrophic obesity. Diabetologia. 2018. https://doi. org/10.1007/s00125-017-4471-4.

51. https://www.invivogen.com/pcpgfree-promoter. Accessed 26 Sept 2019.

52. Liu Q, Li C, Wanga V, Shepherd BE. Covariate-adjusted Spearman's rank correlation with probability-scale residuals. Biometrics. 2018. https://doi.org/ 10.1111/biom.12812.

53. Faul F, Erdfelder E, Buchner A, Lang AG. Statistical power analyses using G*Power 3.1: tests for correlation and regression analyses. Behav Res Methods. 2009. https://doi.org/10.3758/BRM.41.4.1149.

\section{Publisher's Note}

Springer Nature remains neutral with regard to jurisdictional claims in published maps and institutional affiliations.

Ready to submit your research? Choose BMC and benefit from:

- fast, convenient online submission

- thorough peer review by experienced researchers in your field

- rapid publication on acceptance

- support for research data, including large and complex data types

- gold Open Access which fosters wider collaboration and increased citations

- maximum visibility for your research: over $100 \mathrm{M}$ website views per year

At BMC, research is always in progress.

Learn more biomedcentral.com/submissions 